\title{
Music making politics: beyond lyrics
}

\author{
M.I. Franklin, Professor of Global Media and Politics, Goldsmiths University of London
}

In this article I argue that considering how any sort of music is made more closely - as sonic material, performance cultures, for whom and on whose terms, is integral to projects exploring the music-politics nexus. The case in point is "My Way", a seemingly apolitical song, as it becomes repurposed: transformed through modes of performance, unusual musical arrangements, and performance contexts. The analysis reveals a deeper, underlying politics of music-making that still needs unpacking: the race, gender, and class dichotomies permeating macro- and micro-level explorations into the links between music, society, and politics. Incorporating a socio-musicological analytical framework that pays attention to how this song works musically, alongside how it can be reshaped through radical performance and production practices, shows how artists in diverging contexts can 're-music' even the most hackneyed song into a form of political engagement.

\section{Introduction}

In 2016, Bob Dylan was awarded the Nobel Prize for Literature. In 2018 Kendrick Lamar became the first Rap artist to win the Pulitzer Prize for Music. Between these two mediatized moments of public recognition, across the race and genre divides of contemporary culture lie many musico-political timelines, recording careers, playlists, and embodied musicalities. This article aims to show why, and how theory and research into the relationship between (the study of) politics and music-making need to move beyond indicators of political relevance that are based on lyrics, an artist 's public persona, public profile or critical acclaim. It explores how one particular song can become an act of resistance, politicized in, and as music in ways that go beyond lyrical content.

\section{Scene-Setting}

It was an uncharacteristic move for the Nobel Committee to award awarded singer-songwriter Bob Dylan the $113^{\text {th }}$ Nobel Prize for Literature, the first American since the African American novelist, Toni Morrison, in 1993. The prize went to Dylan for his work as a "great poet in the English-speaking tradition" (Danius in Smith-Spark 2016) rather than for his work as a groundbreaking musician. Dylan's seeming indifference created headlines as he delegated Patti Smith, another singer-songwriter and 'punk poet' to receive the prize on his behalf. Smith's rendition of “A Hard Rain's A-Gonna Fall”, released in 
1962 and, since then, prominent on protest-music playlists, generated more controversy after a less-than-word-perfect performance. Inferences drawn about Dylan's political stance towards the Nobel as a cultural institution, about whether this award closed the gap between 'high 'and 'popular' culture were somewhat overshadowed by Donald Trump's election as US President ${ }^{1}$. The Trump inauguration in early 2017 saw a peak in protests, in the US and around the world, against the xenophobic and socioculturally divisive agenda presaged by his campaign. These calls resonated with direct actions, online and in public award ceremonies, against the endemic lack of diversity along race/ethnicity, gender, sexuality, and class axes of inclusion and exclusion that continues to characterize public recognition for artistic and cultural achievement.

\section{Aims and Argument}

The scenario sketched above is this contribution's point of entry for this special issue, conceived for students of the politics-culture nexus interested in music matters ${ }^{2}$. The argument I want to put forward here is that, from this perspective, explorations of music a diverse research domain as well as cultural artefact, art form, and performance practice - need to engage with the full spectrum of classical and popular music research. Scholars along this spectrum have also been considering, through a musicological prism, musicopolitical issues of the day if not the role of musical arts in the longue durée of 'modernity' and its discontents at the macro-level of analysis (Ross 2010, 2011; Said 1993; Attali 1989; Griffiths 2010). The primary aim in this context is to demonstrate - rather than assert by allusion - musically, through close listening to how the making of music can both reveal and resist incumbent powers at the nexus of political and cultural life.

The Nobel Prize for literature was for Dylan's lyrics, not his musical output, nor for his performance art. In this way the award reinforces the idea that aesthetic and cultural value resides in the written or sung logos. In this understanding the materials of 'music', those variously organized 'sounds', serves simply as an accompaniment. Overlooking where and how politics may lie embedded in the musical substance as well as the performance genealogy of any particular piece of music or community of practice means sidestepping a multitude of musical cultures as they crossover into mainstreams (e.g. Jamaican Reggae and Soundsystems cultures, Nigerian Afrobeat, or Brazilian Tropicalismo). These dynamics are not immediately apparent when considerations of music politics/political music focus only on literality-lyrical manifestations. Engaging with musicological modes of analysis can offer students of (international) politics interested in exploring how musicians 'music politics' conceptual and empirical avenues of inquiry ${ }^{3}$.

\footnotetext{
${ }^{1}$ The future of the Nobel Prize as a cultural institution and its international prestige after revelations of sexual harassment, and various sorts of malpractice in 2018 remains to be seen.

${ }^{2}$ This article draws on Franklin $(2019 ; 2020 \mathrm{~b})$

3 "The word "analysis" easily associates itself in music with the idea of all that is dead, sterile and farthest removed from the living work of art. One can well say that the general underlying feeling toward musical analysis is not exactly friendly" (Adorno 2002b, 162)
} 
A third aim is to consider how artists - musicians - have always pushed back against efforts to steer and control their creative and, where apposite, explicitly or implicit political practice for other agendas (Ross 2011; Miller/DJ Spooky 2008). Musicians, as social actors if not activists and artists work intuitively, and consciously to produce artefacts (albums, tracks, works) and performances (live and recorded) in ways that are more than reflections of Realpolitik, reducible to the mimetic in domains, historical periods deemed, or seen as "political" (Hall 1996; Feldman 2017; Rai and Reinelt 2014). The playlist of anti-Vietnam War protest music is one case in point, indeed one in which Dylan's lyrics have been considered formative vehicles for mobilization. For this intervention, however, the main point of critique is that a singular focus on lyrics, literality, is not sufficient to develop analytical frameworks that can apprehend "what makes music work" (Byrne 2012, 10) in politically significant ways. There is a much wider and more diverse repertoire, of performance as well as musical material, within mainstream and marginalized musical cultures, now accessible in concomitant video archives and discographies online than has been assumed for music-based investigations in political research.

These stipulations beg the question of demarcation as well as of definition for projects that are by predilection multidisciplinary undertakings. Music and politics are both areas of scholarly, practical and technical expertise even as their respective performance mores, methodologies, and theoretical canons run along parallel lines in contemporary academe. In the case of political science, particularly the study of international relations - world politics or global politics (Caso and Hamilton 2015; Zehfuss and Edkins 2019), intra-disciplinary debates are anchored in the historiography of the nation-state and the Westphalian state-system, recent transformations through critique in both respects notwithstanding. Such reconsiderations of main objects, modes and levels of analysis have their counterparts in music research: comparable shifts around core objects of analysis (the music 'work' as artefact), empirical categories, privileging of the musical form and substance of western tonality. These have led to shifts in the Eurocentric musical centre of gravity to consider race, class, gender and sexuality as constituent elements rather than epiphenomena of music theory and research ${ }^{4}$.

\section{Organization}

Two conceptual, historiographical points underpin the argument driving this analysis in this regard: First is the ethnocentric teleology of what are often unquestioning emotional ties to the tonal 'home' upon which western music-making cultures are based, standardized systems of major and minor scales (even when other scales are deployed across the musical spectrum). This (acquired) way of hearing only certain sonic organizations as music (or not) undergird theories, and histories of western music and society within a narrative of inevitability that posits the western European experience of (musical and

\footnotetext{
${ }^{4}$ I discuss these matters more fully in Franklin (2020a; 2020b)
} 
political) modernity as the peak of political and cultural achievements. Jacques Attali (1989) is a prominent example of this line of thought. Alex Ross $(2010 ; 2011)$ provides a more nuanced exploration of the relationship between (late) modernity, twentieth century ideologies, and western classical/popular music, as do Barenboim and Said (2003), and Said (1992). Barrett (2016) deconstructs this whole enterprise by questioning the very supposition that 'music' is defined only by its sonic qualities, as variously organized sound. The writings of Theodor Adorno on music weave in and out of these treatises by virtue of his provocative critiques of the sociocultural and political legacy of the western classical music tradition in the wake of how exponents of $20^{\text {th }}$ century - "new" or modern - music can atone for the cultural establishment's complicity with totalitarian and capitalist forces of oppression (Adorno 2002a; 2002b).

Second, these associations undergird a widespread assumption that there is but a limited repertoire in aesthetic positions, experience and musical (gendered and racialized) prowess from which to evaluate diverse music-making as cultural and politically significant forces. There is still much light to be shone on the uneven cultural geographies of musical taste - aesthetics and criticism, given the ethnocentric filters that evaluate, and tabulate ways of making music and politics from either side of what remains the ethnocentric, western musical norm. The flipside to this conceptual blind spot is how, despite its market power and capriciousness, the global music industry of today cannot completely control the ways in which music operates as transferable, polysemic politics. Record companies and radio DJs cannot entirely dictate where and how a piece of music, a performance becomes political/politicized, or how people and communities respond as music artefacts-as-performance circulate through diverse locations of experience and sociopolitical polarization (Rühlig 2016; Zuberi 2017). Third, how political power and resistance become intimately part of how musicians change, adapt or reconstruct any part of their own - or others' - repertoire offers possibilities for unpacking the politics of $f a$ miliar music. Doing so requires analytical approaches that can consider music/s as mobile rather than static artefacts or cultural practices, as more than passive instruments for domination, or as a machine-readable soundtrack for liberation struggles reflected through lyrical intentionality.

The article proceeds as follows, moving along the spectrum that spans the socalled 'levels of analysis' problem as it goes. The empirical focus is an example of one particular, apolitical and barely regarded as potentially political song, "My Way". It serves as a rich vein of inquiry for explorations of how music works politically in ways that go beyond manifest lyrical content or performance genealogies marked as appropriate contributions to political spectacle. Before exploring selected performances of "My Way" the article first considers some of the conceptual points that arise at this disciplinary intersection. It then unpacks how this song works musically, on its own terms and in the case of three artists who have reworked it across historical time, geocultural space, race and gender divides in particular. This popular standard, one that many 'love to hate', underscores how, in the right hands, it can trounce the performance conventions attributed to its designation as schmaltz, a 'Crooner Classic', much loved in Karaoke bars and 
funerals. This tripartite analysis pivots on the invidious ways in which the notion of an incommensurable (rather than a socio-politically constructed) race-divide that keeps Black epistemologically segregated from White music-making, music scholarship and journalism continues to play a formative role: not only in prize-giving ceremonies, mainstream or self-designated "alternative" radio and streaming playlists but also in scholarly debates around revisionist histories of twentieth century music, as an art form, entertainment industry, and social engagement.

\section{Conceptual and Contextual Relays}

Imagine being in the audience, back in the winter of 2016 in Stockholm, as Patti Smith takes to the stage, dressed in a formal-like white shirt under her trademark black overcoat and waits at the microphone for her cue to the first verse of Nobel Laureate, Bob Dylan's “A Hard Rain".. What happens next, and whether as audience or YouTube viewer you would rate this version of the song as either great poetry, great music, or a great performance notwithstanding, the gender-race infused cultural politics of this moment are palpable even at a distance. Both Smith and Dylan were born in the 1940's, and made their mark in mid- $20^{\text {th }}$ century, New York underground cultural scenes as these intersected with the rapid internationalization of anti-Vietnam war and civil rights protest movements of the time. Yet here 'they 'are, accepting an honour in a European cultural institution whose official preclusion of music as an award category underscores the global reach, hegemonic power that Anglo-American popular culture exerts on everyday and politically aware playlists. The extensiveness of this reach, through the market dominance of Anglo-American film, television, and music conglomerations, and of English as a world language, goes hand-in-hand with the historical trajectory of US military and geopolitical power. It also traces global imaginaries of individual, community, and organized resistances to abuses of power for which these playlists provide familiar soundtracks, notable exceptions notwithstanding (Miller/DJ Spooky 2004, 2008; Gilroy 1993; Krims 2000). In this respect those rooted in the African American experience, of slavery and racial segregation, continue to express and challenge the racial cleavage that still defines American public life. In so doing they constantly re-echo these other histories, invert the triumphant narrative of Anglo-American (read: white, settler) economic and military prowess, political and cultural exceptionalism. Dylan's œuvre encapsulates one musicalnarrative arc of experience and possible dissent to these forces, even though he has publicly rejected being labelled a political artist.

The literature is only just beginning to consider the sonic dimensions to waves of mobilization around civil rights, women's liberation, and anti-racism from other parts of the world (Dillon et al 2020). These new areas of inquiry follow in the wake of a major shift in how "music" has been conceptualized, in classical art music and popular music studies, from a static object to a mobile practice, from artefact to relationships. Muiscking 
is a much-cited term coined by Christopher Small $(1998,13)$ who was at the vanguard of this shift.

Small lays the stress on music-making as a process and set of relationships, rather than 'music 'as a noun, a static, ahistorical object of analysis, or field of intellectual, aesthetic appreciation in isolation. Small's conceptualization encapsulates moves in this period away from the "absolute music" tradition that dominated theory and analysis in the classical art music tradition (Barrett 2016) towards the study of musicking - music - as multivariate forms, and communities of practice that comprise social - and, thereby, political - communication.

These socially constructivist approaches have been formative in popular music theory and research with its focus on lyrical meanings, reception/audience studies and affect. Regarding music as socially embedded has also informed critiques of the World Music business model, and related debates in ethnomusicology around the limits to western conceptual models of musical form when looking to apprehend how the music of other cultures works (Feld 1996; Mowitt 2002, 211; Franklin 2005). This shift in emphasis need not exclude paying close attention to how any piece of music, or categories of music-making co-constitute these relationships as sonic artefacts, ways of (re)organizing, if not manipulating sounds by adapting some of the tools of musicological analysis (Davies and Franklin 2015).

How does this shift from noun to verb work as/in any piece of music, or musical practice? By way of illustration a singer-songwriter-author who was much less coy about the political reverberations in which they worked, is Gil Scott-Heron; an exemplar of these dynamics (1949-2011). Scott-Heron, heralded as a "New Black Poet" with the release of his first album, Small Talk at $125^{\text {th }}$ and Lenox, in 1970, was from the same generation as Bob Dylan and Patti Smith.

Scott-Heron devoted his whole career to voicing these contradictions, re-scoring and so making audible silences in the official play-list, and business model of the largely US-owned global arts and entertainment industry. He also played no small part in the success of mobilization, led by Stevie Wonder, to establish a national holiday to commemorate Dr Martin Luther King. Scott-Heron did this as a pioneering exponent of another sort of "musicking" to those that comprise the western classical and popular music canon, now a global market-leader in music sales and a multidimensional commercial and cultural force in its own right. The musicking that Gil Scott-Heron's work came to encapsulate, in its earlier articulations, is Rap and Hip Hop through he preferred to call himself a "Bluesologist" (Scott-Heron 2012).

Emerging from poor, Black urban neighbourhoods in the US East and then West Coast in the 1970's - 1980's, Rap music and concomitant Hip-hop culture are intimately connected to a form and style of socio-politically conscious music-making. These commentaries on the frustrations, violence and injustices of socio-economic deprivation, and racism in the everyday lives of millions of Black Americans continue to resonate with ethnic minorities in other parts of the world. As a musical and spoken-word practice Rap draws on African/African diasporic musical cultures (rhythms, beats, and instruments), 
Jamaican reggae and dub traditions (improvisation, 'scratching' techniques with record turntables, the dialogue between $M C$ and audience, and the 'selector' influence of Deejaying).

From the outset it made free use of tropes from African American blues and jazz musical cultures through a range of lo-tech and, later, digital forms of musical "borrowing" from previous recordings, now called sampling. Borrowing, directly or indirectly through figurative and literal forms of musical quotations, said 'sampling', generates a complex interplay between horizontal and vertical layers that move the track along, and hold it together (Katz 2004; Laderman and Westrup 2014). Lyrically, Rap and Hip-hop is based on delivering material that is spoken/sung as both rhythmic and substantive, figurative meaning making with, and alongside sampled material. These are contemporary, musicalized expressions of longstanding cultures of intra-cultural and intergenerational conversation comprised of the tropes, and (self/community) consciousness of Black vernacular speech. Scholars study these communicative cultures as exemplars of $\operatorname{signifyin}(g)$ as spoken, and musical practices (Gates 1988, xxix-xxxiii; Rose 1994; Krims 2000).

\section{Musicking Politics in Practice - "My Way"}

We can now turn the case in point in light of the conceptual and musico-historical points made so far. The discussion herein considers what happens when, and how a song is made to sound, how it sounds, in different musical ways that reverberate with the respective changes in sociocultural or political contexts and the artist's own sensibility. Even without lyrics that are explicitly political, or forms of social commentary on current events, a pop song can also emerge as a 'conscious' contribution to wider issues.

The example, "My Way", was a hit in the 1960's. It originated in France, embedded in the French-language chanson tradition and its pantheon of superstars (Claude François, France Gall, Jacques Brel for instance). The song has come a long way since then. Travelling, first, across the Channel to the UK briefly but then onwards across the Atlantic, "My Way" was a chart-topper for both Frank Sinatra in 1969 and Elvis Presley in 1973; covered and caricatured countless times since.

The original song, "Comme d'habitude", co-written by Jacques Revaux and Claude François, was first released in 1967. The melancholy title ('As usual' or, rather, to fit the melodic line; 'like you/I always do') and lyrical storyline are carried by a simple, sing-able melody which is based on the upward movement of an interval called a rising sixth. The original lyric ruminates on the pending end of a relationship, a common theme in pop songs. It was the American singer-songwriter, Paul Anka, who bought the rights to adapt the song. David Bowie attempted his own text over the original melody with considerably less success (according to Bowie) at about the same time. Anka changed the words, the number of stanzas, and the title. The first line, "And now, the end is near, and so I face the final curtain..." shifts the sentiment from bittersweet ruminations on a 
relationship ending to an, arguably, defiant affirmation of individual agency and determination: "I did it my way" 5 .

This malleability is one clue, perhaps, to the song's longevity. As we will see below, it seems to enable artists to articulate an inner world of emotions and at the same time - in the same bar, or breath even, gesture towards broader societal issues. The melodic structure and basic harmonic lines did not change significantly between the original and Anka's adaptation, however. But this is not why this example is of interest to this inquiry, the immediate impact that changing a lyric can have on how people can respond to a song notwithstanding. It is the geocultural and symbolic border-crossing qualities to this song's inter-national, and intra-cultural trajectory over the last fifty years that provide insights, on listening again, into the dynamism, the porousness of any musical tradition, or artefact, as it travels through time and (cyber)space. These shifts emerge as performers re-adapt, and then re-deploy the musical elements in question. Precisely because the lyrics of this song are not overtly political, neither in the original French nor English versions, how these shifts in register resonate with not only the socio-political but also the commercial context in which they emerge becomes possible to follow and hear.

\section{Sid Vicious' Way}

In 1978, the song took on a completely different, socially antagonistic demeanour when Sid Vicious, from the British Punk band, The Sex Pistols, covered it. The video-clip of this version, taken from the album, and film called The Great Rock ' $n$ ' Roll Swindle (Dir. Julien Temple 1980), opens with Vicious descending a staircase onto the stage to a descending orchestral glissando. In a white blazer (crooner-style), Vicious (born John Simon Ritchie) takes to the microphone and sneeringly sings, off-key, the first four verses; "And, now, the end is near". At the moment of the next four more verses his subversive intentions become clear. There is brief pause, orchestral glissando again, and then the electric guitar takes off, doubling the beat as Vicious modulates from croon to scream to complete the song. The audience is pictured as both shocked, and in raptures as Vicious riffs on the lyrics with copious expletives.

The effect of this break from the archetypical delivery of this song was electrifying at the time and it still is, for more reasons than the visual cues might suggest. The double-target is clear, mainstream classical concert cultures and, on the other hand, the trappings of fame and fandom - punk made audience-confrontation an intrinsic element in the performance - that sustains the music business. The video ends with Vicious pulling a gun, and then shooting into the audience of mostly older white, well-dressed

\footnotetext{
${ }^{5}$ Paul Anka negotiated the rights to adapt and record the song, sharing the proceeds with Revaux and Francois, until the French entrepreneur Xavier Niel bought the French rights in 2009. Anka apparently considered the original a "shitty" song but one with potential. Frank Sinatra apparently despised this "self-indulgent" version (BBC 2000).
} 
concertgoers. Pandemonium, punk-style, ensues. Vicious gestures obscenely to his 'victims', to then re-ascend the staircase.

He did it not just 'His Way' 'but 'Another Way'. Vicious - 20 years old at the time - takes this crooner-classic well out of its comfort-zone, and original social context in order to sound another sensibility about status, value, and what counts musically. This mise-en-scène encapsulates the challenge of Punk as the transgressive youth movement of the day. It also signals some of its future contradictions as a musical innovation, and shifting status over the next forty-odd years; from a grassroots form of socio-economic protest against the vested order of class and privilege to a global, and commercial phenomenon encompassing fashion, alternative media, and major publishing outlets, and archive for subsequent counter-cultural statements (Davies 2005; Dunn 2016; Reddington 2007).

\section{Nina Simone's Way}

Issues of class-exclusion and identity politics are evoked in this Punk version of "My Way". Other approaches to the song trace the race dimensions at the intersection of class and gender axes of exclusion, in life and in the music business. The first is characterized by the formative musical contribution, not only the commercial success, of Black artists across the racially encoded commercial divide that still governs the global business model of music marketing and its African/African American centres of gravity (Gilroy 1993; Gates 1988).

These other examples throw into relief inter-generational dynamics of race, gender and sexuality when considered in light of the entrenched under-representation of women composers and musicians, in classical art-music and popular music domains as well as in writing about music. The African American singer-songwriter, and classically trained musician, Nina Simone, exemplifies these dynamics. Like Gil Scott-Heron, Simone (born Eunice Kathleen Waymon) was raised in the southern states of the USA. She became prominent during the 1960's civil rights struggles led by Martin Luther King, at his side in the March on the Selma to Montgomery (Alabama) marches in 1965. Simone penned a number of world-renowned anthems of the Civil Rights movement and was politically outspoken all her life. She eventually left the US (claiming that she was pursued and threatened by the authorities) to live and perform in exile, in Liberia, and France where she died in 2003, at the age of seventy.

In 1971, Simone, released her (single) version of "My Way", with RCA Victor Records. It was included on the Here Comes the Sun album of the same year. The audio of this release is (currently) available on YouTube ${ }^{6}$. One of the hundreds of comments on this clip, posted by Gérard Derwael in 2017, goes to some length to articulate what makes

\footnotetext{
${ }^{6}$ The single was released in France, Spain and the Netherlands between 1971 and 1972 with the original French title on the first two releases' sleeve.
} 
It is no longer on the penultimate syllable - I did it MYYYY way, reiterated any number of times in grand finales (these five words-syllables are usually held for at least four beats, extended and modulated upwards in varying degrees of volume, or emotional embellishment by the vocalist). In so doing, the addressee and positioning of the subject/object relations within the manifest content shifts as well; myway as rage but also as part of an intimate conversation with another (male) other as Simone then subtly shifts the line 'what is a man, what has he got' to 'what is a man what have you got---' in the last third of this studio performance.

The Afro-Caribbean rhythm, jazz keyboard inflections, and Gospel-based delivery are part of three, interwoven yet equal sonic lines. "My Way" has crossed the racialized genre-gender divide, redrawn it, thrown it back, and "spat it out". Simone delivers those lines (one minute, forty-four seconds into the track), "I ate it up, and spat it out, I ---------- stood tall, I did it my-way" by roaring, figuratively spitting the words out, to then hold the first person for four beats before moving into the aforementioned rhythmic motif on "myway". In these respects, her delivery, from a different musico-time and politico-cultural place, presages later punk, and Rap/Hip-hop versions ${ }^{8}$.

Nina Hagen's Way

One other version should suffice to show another dimension to how music-making becomes politics. It is by another Nina, Nina Hagen. Hagen also improvises, extends, and reshapes the piece in a way quite similar to the Punk version now identified with Sid Vicious. Hagen, raised in East Berlin and trained as an opera-singer with a complex relationship to her East German roots and career in the West, has been covering this song for some time. One of two versions can be heard in the live recording of one of the many concerts held as the Berlin Wall collapsed in 1989. The one that Hagen took part in was a rock concert. The other was a classical concert, of Beethoven and Mozart, conducted by Daniel Barenboim ${ }^{9}$.

There is, however, an earlier version from 1978 that comes very close to the Sid Vicious cover, recorded in April 1978 in Paris though only released in 1979 according to one source (Géant-Vert 2004). The similarities (if not in the vocal pyrotechnics) include the opening glissando on synthesizer in the Hagen's version, slow intro and transition to loud, fast, and raucous, albeit with a different sort of guitar riff to segue from ballad to punk-rock anthem. In both performances, Hagen also proceeds to improvise, in German ${ }^{10}$.

\footnotetext{
${ }^{8}$ Rapper Jay-Z released his version of "My Way", a rap-inflected dialogue interpolated between the Anka lyrics and entitled "I Did it My Way" on his 2002 album, The Blueprint 2: The Gift \& The Curse.

${ }^{9}$ The 1989 concert for citizens of the GDR this classical concert took place on $12^{\text {th }}$ November 1989 . Hagen performed her version of $M y$ Way at a free concert organized by the radio station, Senders Freies Berlin (SFB), two days earlier, released in 2014 as a compilation with Universal Music's Panorama label as Mauerfall - Das legendäre Konzert für Berlin '89 (KlassikAkzente 2014).

${ }^{10}$ The clip from Hagen's 1978 performance is taken from a show in Dortmund, in December of that year, also available on YouTube at: https://www.youtube.com/watch?v=MHEwCagBtN0. Lyrically, this
} 
The years separating these two performances provide their own slant on her lyrics, then and in retrospect. The first person, "I" of "My Way", becomes the communal 'we' of 'our way' in the geopolitical and cultural aftermath of the collapse of the Berlin Wall and associated demise of the Soviet Union.

'Recap' - Whose music-politics is (made) audible?

This discussion has aimed to show, socio-musicologically, how political forces modulate as musicalized expressions of resistance, as much as compliance. These modulations can become discernible within the most hackneyed of examples along with others considered "living works of art" (Adorno 2002b, 164) in the literature. Aware of the limits to Adorno's own, infamously delimited playlist, I have followed his cue that musical analysis need not only be about describing formal structures (harmony, melody, rhythm and other 'materials of music'). Rather that it also entails developing ways to engage in "structural listening [to] what is going on, musically, underneath these formal schemata" (Adorno 2002b, 164).

Getting underneath also involves considering what is going on, culturally as well as musically around the analytical, or commercial categories that distinguish one musical form, communities of practice, and measure of creativity, from one another. This means breaking the habit of locking the political, or any other meaning in the manifest - literal - lyrical content alone.

Several conclusions can be drawn for future explorations in to musicking politics that go beyond lyrical reductionism on the one hand and, on the other, the anti-musicality of positivist empiricism. First, the cultural and political spheres, however demarcated these may be from one another in the literature or through institutionalized communities of practice and taste, are not a priori separate domains of human endeavour with mutually exclusive hierarchies of power, privilege, and influence. But this does not mean to say that these two domains are synonymous, or to deny that music/s can be manipulated or repressed for political agendas. The historical record shows many examples of musicians, like other artists, grappling with the impositions, indeed dangers, of upsetting incumbent powers (Şener 2013; Ozturkmen and Martin 2014; Rühlig 2016; Miller/DJ Spooky 2004, 2008).

Through the case of "My Way", we can now hear how a piece of music, musicking dynamics (re-)articulate politics in ways that can both conforms to - and defy - powerful forces of control and obedience. For analysis these dynamics can be couched as literality only up to a point given how musicians use the power of suggestion, connotation, and interplays between familiar and introduced sonic, performance, and (as the case may be) lyrical elements.

version is mostly her own, German take on the lyrics ("Die Welt ist so kaputt....") after delivering the first verse of the English lyric 
In the second instance, the Nobel Prize 'rebranding' of Bob Dylan's musico-poetics as 'high art' throws it into relief the gatekeeping powers of cultural institutions at home and abroad as they seek to control cultural agendas, mitigate sociopolitical critique. In this case the honour of inclusion is reserved for a global superstar whose career is as much embedded in the trajectory of political and social commentary on his work as it is in the economic hegemony of the Anglo-American "Culture Industry" (Horkheimer and Adorno 1944). Much ink has been spilt to argue that whilst art may want to be political it may not necessarily 'work' as good 'art'.

Such concerns are political as much as they are aesthetic and, thereby, cultural and ethical questions. Many artists and musicians, several of whom have been discussed here, have combined their political and artistic commitments effectively, and without any sense that there need be a compromise. Vested interests, political and economic powers of ownership and control continually look to take charge of any cultural agenda from funding through to programming. For centuries, musicians, like any other artists, have been navigating these minefields of patronage, copyright, legitimacy, creative autonomy, and obstacles to dissemination.

Third, this discussion reconsiders questions about how music communicates, and for what purpose, in order to suggest that such an inquiry, whatever the disciplinary perspective or musical preference, needs rephrasing. Different sorts and communities of music, apprehended as more than the sum of formalized, theoretical properties, have always travelled; geographically and now via informal and commercialised computer-networked domains.

The communities of practice, and the artefacts that are produced when people, as individuals, groups or communities, come together to make and listen to any sort of music, need to be considered not in isolation. Rather, they need to be apprehended as complex wholes, "travelling cultures" that are not entirely reducible to their socio-historical timelines, or politico-cultural associations (Clifford 1998). Moreover, as a predominantly sonic, spontaneous and yet also consciously crafted force, music/s also travel physically; through the airwaves as beat, pulsations in varying frequencies, vibrations, as acoustic or amplified volumes of sound organized as melody, chord clusters, vocal or instrumental configurations, pitch and rhythm.

People were singing, making and playing 'found' or crafted instruments, and sonically-poetically articulating the world around them long before the portable audio cultures that emerged with the invention of recording technologies; from the phonograph, through to the tape recorder, Walkman, Discman, iPod and, 24/7 live-streaming services. In this respect, it is a truism to observe that music is everywhere, even when it is being heard in places some might prefer it not be - from the thud of the neighbour's soundsystem on the other side of the wall, to tailor-made forms of background muzak in lifts, hotel lobbies or shopping malls. It may be everywhere but the diversity, and richness of audio cultures in the round is unevenly available.

So, fourth, whilst it is, indeed, an audible world, not everyone is listening and/or is able to practice or experience the diversity of these sonic cultures in equal measure. 
This skewed geocultural terrain is shaped by the preferences for the music of some segments of society. The ability to hear, to be able to listen to music that is unfamiliar in form (neither three-minute pop-song, folk standard, nor classical symphony) or content (unusual harmonies or melodic lines, lyrics in another language, atypical instruments or instrumentation), is also shaped by habit and fashion, socialized by the play-lists of commercial and cultural institutions; from public radio stations through to school and university curricula through to funding for community centres, to concert-hall programs.

A key problem in this regard is the undertow in the literature that assumes that there is an "isomorphism" between any music, as practice and artefact, and its provenance, then reduced to reified indicators of race, gender, class, and sexuality (let alone religious affiliation). Like all cultural forms, art included, the sociopolitical, if not economic conditions of inception, realization, and reception by others are reconfigured in the act of musicking, listening, or remixing. These conditions can affect, and do inflect, what an audience or circumstantial listener might (be able to) hear. This is where most of the fiercest debates that patrol the boundaries of writing on western classical art music and other kinds of music - those from other cultures are lumped together under the world music rubric of commercial marketing genres - can be found.

Scientists, psychologists, and philosophers of music still argue over whether any sort of music can directly influence attitudes and actions, in an unmediated or decontextualized way. As noted above, the historical record shows that both incumbent and emerging powers - be they social, political, or religious authorities - seek to control cultural life. This includes punitive responses to musical forms of expression and communities deemed culturally suspect, transgressive, or a direct challenge to the status quo. Silencing opposition is, particularly in the case of sound waves, a physical as well as a political act of violence.

Here lies the paradox, the moment of possibility. Once physical distance made access to the music/s of others difficult for potential, non-accredited listeners. In a time when all sounds can arrive through the airwaves, live-streamed or replayed on analogue (vinyl records and turntable cultures are alive and well) or digital recording devices, symbolic and material borders can be traversed and repurposed. Back-catalogues and innovations can be made accessible by ordinary people wanting others to hear something they want to share, and by musicians (Byrne 2012, 81-145; Katz 2004; Stratton and Zuberi 2016; Zuberi 2017).

As powerful agents look to control agendas, responses from artists to the imposition of cemented, rather than the encouragement of 'invented' traditions are integral to apprehending how music is made, how it 'works', and for whom. These counter-cultural forces can be traced in the objectives of the avant-garde and experimental schools on classical art music from the mid-20 $0^{\text {th }}$ century to challenge the rigidities of the western classical canon, setting up an international network of musical centres on doing do and collaborating with popular music exponents as well. Another sort of pushback is evident in the way that the Do-It-Yourself musical and visual cultures of punk politics and the $\operatorname{signifyin}(g)$ practices of conscious Rap/Hip-hop reinvent themselves for contemporary 
contexts. These sorts of musicking, and many more, initially made their mark by challenging the way that corporations benefit from the revenues raised by licensing and copyright arrangements.

Challenges to direct (bans), or indirect (media panics) forms of censorship also include contemporary expressions of cultural - racial and religious - music diversity by successive generations of former colonial subjects living in Europe and, more recently, brought by the 65 million people around the world suffering, and surviving the hardships of forced displacement. Music is listened to and made in refugee camps, in besieged cities as bombs fall, in detention centres on the borders, and in penal institutions. These $m u$ sickings are also travelling cultures and, thereby, have political resonance. These phenomena need not be confined to the category of overtly political song, such as Simone's "Young, Gifted, and Black". It can also happen with the most mainstream examples of music, emanating from any vested order, as artists transform, and reinvent these sounds, musical structures and idioms, in ways that challenge, rather than reproduce sociocultural, economic and political divides along race, class, gender and, nowadays, religion. As they do, these soundings (with or without words) can, and do travel outwards as they move through, and around all possible worlds, evoking multiplex - mixed, not fixed - cultural imaginaries along the way.

\section{'Outro': Are times a-changing? ${ }^{11}$}

In an interview in 1985, Nina Simone speaks about her musical politics, and with that her political philosophy of music, making here no a priori distinction between "masters" such as JS Bach and key figures in the canon of what she calls "Black Classical Music" such as John Coltrane or Miles Davis. Her love and knowledge of the classical canon is clear in this conversation. Simone, trained as a classical pianist, was refused entry to the music Conservatorium in the still segregated south, which is a recurring theme in her interviews. This interview takes place alongside her performing in the studio a version of her "first civil rights song" from 1964, "Mississippi Goddam". What she does midway through playing this, relatively introspective, version of the song encapsulates the complexity of this subject matter.

In this performance, Simone transitions in and out of the musical-spoken commentary as she moves sonically, and figuratively, outwards and back between two historical and socio-political points of reference ${ }^{12}$. The way she plays, and speaks, exemplifies her artistry, anti-racism politics, and embodied performance practice infused with her commitment and ability to draw on multiple traditions (Gaines 2013). Midway in this

\footnotetext{
${ }^{11}$ With no apologies for borrowing from Bob Dylan's “The Times They Are A-Changin” (1964)

12 Feldstein considers some of the possible reasons why Simone's artistic and political contribution to key events in American public culture in light of that of others from her generation of artists and activists remains under-recognized; down to more than the official narrative of her being a "difficult woman" (Feldstein 2005, 1351).
} 
performance Simone pauses at the piano. Over the (pre-country music associations of) 'honky-tonk' chords and rhythm upon which "Mississippi Goddam" is based, she states that this song is written; "as you know, by Nina Simone; very much like in $1932 \ldots$ in which at that time Bertolt Brecht and Kurt Weill wrote another song called "Moon Over Alabama" ... What we're going to do is combine "Mississippi Goddam" with "Moon Over Alabama"”.

Without missing a beat Simone then segues effortlessly into her rendition of "Moon Over Alabama along to the same rhythmic pulse as "Mississippi Goddam" adjusting but also riffing on Weil's melodic line. The former song, sung in English for an otherwise German libretto, opens with the lines, "Show me the way to the next whiskey bar ...I tell you we must die"13. With a fistful of dissonant chords serving as a bridge, she then modulates back to the first line of "Mississippi Goddam", "Alabama's got me so upset..."14. As the interview continues Simone explains why she chose this track to perform:

"I sing it for two reasons... First it's one of the biggest songs I ever made. Secondly ... no one really commemorated or remembered, in my opinion, enough Martin Luther King and "Mississippi Goddam" brings him back ...Because youth need to know the history of America... They need to know what we did there... is still alive in the minds and ears of young people. And that is my contribution."

A national holiday commemorating the life and work of Martin Luther King Jr. eventually passed into American law in 1986. It is observed on the third Monday of January every year. Along with Stevie Wonder, artist-campaigners like Gil Scott-Heron and Nina Simone were able to take part in this inaugural holiday. Twenty years for this to happen was, back then, indeed a very long time (Scott-Heron 2010, 5). And since then, in light of the public recognition of Rap and Hip-hop with Kendrick Lamar's 2018 Pulitzer Prize for Music, Nina Simone's outrage still resonates today: "Too Slow!"

\footnotetext{
13 This is from the 2003 DVD, Nina Simone - Live at Ronnie Scott's (Dir. Steve Cleary and Rob Lemkin: Quantum Leap), recorded in November 1985. "Moon Over Alabama", or the "Alabama Song", is the best-known number from Kurt Weill and Bertolt Brecht's Rise and Fall of the City of Mahagonny (Aufstieg und Fall der Stadt Mahagonny)

${ }^{14}$ Feldstein goes into more detail about the political undertones of this song in with lyrics "filled with anger and despair ... in stark contrast to the fast-paced and rollicking rhythm" $(2005,1349-50)$.
} 
References

Adorno, T.W. (2002a [1938]). On the Fetish-Character in Music and the Regression of Listening. In: R. Leppert, ed., Essays on Music: Theodor W. Adorno. Berkeley, Los Angeles: University of California Press, pp. 288-317. https://doi.org/10. 7202/1014679ar

Adorno, T.W. (2002b [1969]). On the Problem of Music Analysis. In: R. Leppert, ed., Essays on Music: Theodor W. Adorno. Berkeley, Los Angeles: University of California Press, pp. 162-180. https://doi.org/10.7202/1014679ar

Attali, J. (1989). Noise: The Political Economy of Music. Translated by Brian Massumi. Minneapolis: University of Minnesota Press.

Barenboim, D. and Said, E.W. (2003). Parallels and Paradoxes: Explorations in Music and Society. New York: Pantheon Books.

Barrett, G.D. (2016). After Sound: Toward a Critical Music. New York, London, Oxford: Bloomsbury Academic.

BBC News (2000). Sinatra 'loathed' My Way. BBC News. Available at: http://news.bbc.co.uk/2/hi/entertainment/994742.stm

Byrne, D. (2012). How Music Works. Edinburgh UK: Canongate.

Clifford, J. (1998). Routes: Travel and Translation in the Late Twentieth Century. Boston: Harvard University Press. https://doi.org/10.2307/3034525

Caso, F. and Hamilton, C. (2015). Popular Culture and World Politics: Theories, Methods, Pedagogies, Bristol, UK: E-International Relations Publishing.

Davies, M. (2005). Do It Yourself Punk Rock and the Disalienation of International Relations. In: M.I. Franklin, ed., Resounding International Relations: On Music, Culture, and Politics. New York: Palgrave Macmillan: 113-140. https://doi.org/ 10.1007/978-1-137-05617-7_6

Davies, M. and Franklin, M.I. (2015). What does (the Study of) World Politics Sound Like? In: F. Caso and C. Hamilton, eds., Popular Culture and World Politics: Theories, Methods, Pedagogies. Bristol, UK: E-International Relations Publishing, pp. 120-147.

Dillane A., Power M. J., Devereux E., and Haynes, A. (2020). Songs of Social Protest: International Perspectives. New York: Rowman and Littlefield.

Doran, J. (2017). Vanishing: Where Is The Music Of The Impending Apocalypse?. The Quietus. Available at: http://thequietus.com/articles/22260-vanishing-apocalypse -end-of-the-world-shellac-botanist

Dunn, K. (2016.). Global Punk: Resistance and Rebellion in Everyday Life. London: Bloomsbury. https://doi.org/10.5040/9781501314636.ch-001

Feld, S. (1996).“Pygmy POP. A Genealogy of Schizophonic Mimesis. Yearbook for Traditional Music, vol. 28(1996), pp. 1-35. https://doi.org/10.2307/767805

Feldman, Z. (2017). The Politics of Visibility and Art. London: I.B. Tauris. https://doi.org/10.5040/9781350985407 
Feldstein, R. (2005). 'I don't trust you anymore': Nina Simone, Culture, and Black Activism in the 1960s. Journal of American History, vol. 91(4), pp. 1349-1379. https://doi.org/10.2307/3660176

Franklin, M.I. (2005). Resounding International Relations: On Music, Culture, and Politics. New York: Palgrave. https://doi.org/10.1007/978-1-137-05617-7

Franklin, M.I. (2019). Um die Welt mit einem Song. In: R. Grätz and C. Höppner, eds., Musik öffnet Welten: Zur Gestaltung Internationaler Kulturbeziehungen. Institut für Auslandsbeziehungen, Deutscher Musikrat, Göttingen: Steidl Verlag, pp. 115130

Franklin M.I. (2020a). Sampling Politics: Music and the Geocultural. New York/London: Oxford University Press (in press).

Franklin, M.I. (2020b). Music: Women Rewriting Punk Performance Politics. In: S. Rai, S. Jestrovic, M. Gluhovic, and M. Saward, eds., the Oxford University Press Handbook of Politics and Performance. London/New York: Oxford University Press (in press).

Gaines, M. (2013). The Quadruple-Consciousness of Nina Simone. Women \& Performance: a journal of feminist theory, vol. (23)2, pp. 248-267. https://doi.org/10. 1080/0740770x.2013.825428

Géant-Vert (2004). "Sid Vicious - My Way" on God Save The Sex Pistols CPhil Singleton. Available at: www.sex-pistols.net; http://www.philjens.plus.com/ pistols/pistols/pistols_sid_myway.htm

Gates, H. L. Jr. (1988). The Signifying Monkey: A Theory of African-American Literary Criticism. Oxford University Press.

Gilroy, P. (1993). The Black Atlantic: Modernity and Double Consciousness. Cambridge: University of Harvard.

Griffiths, P. (2010). Modern Music and After. $3^{\text {rd }}$ edition. London/New York: Oxford

Hall, S. (1996). New Ethnicities. In: D. Morley and K.-H. Chen, eds., Stuart Hall: Critical Dialogues in Cultural Studies. London; New York: Routledge, pp. 441-449. https://doi.org/10.4324/9780203993262

Horkheimer, M., and Adorno, T.W. (2002 [1944]). Dialectic of Enlightenment: Philosophical Fragments, translated by E. Jephcott. Stanford, California: Stanford University Press.

Katz, M. (2004). Capturing Sound: How Technology Has Changed Music. University of California Press.

KlasskikAkzente.de (2014). Konzert für Berlin '89: Mauerfall und das legendäre Konzert für Berlin '89. Available at: https://www.klassikakzente.de/konzert-fuer-berlin/news-und-rezensionen/mauerfall-und-das-legendaere-konzert-fuer-berlin-89230674

Krims, A. (2000). Rap Music and the Poetics of Identity. Cambridge and New York: Cambridge University Press.

Laderman, D. and Westrup, L. (2014). Sampling Media. New York, London: Oxford University Press. https://doi.org/10.1093/acprof:oso/9780199949311.001.0001 
Longhurst, B. and Bogdanović, D. (2014). Popular Music and Society. $3^{\text {rd }}$ edition. London: Polity Press.

Miller, P.D./DJ Spooky (2004). Rhythm Science. Boston: MIT Press.

Miller, P.D./DJ Spooky (2008). SOUND UNBOUND: Sampling Digital Music and Culture- Boston: MIT Press. https://doi.org/10.7551/mitpress/7723.001.0001

Mowitt, J. (2002). Percussion: Drumming, Beating, Striking. Durham and London: Duke University Press. https://doi.org/10.1215/9780822383604

Ozturkmen, A., \& Martin, C. (2014). The Park, and Penguin, and the Gas: Performance in Progress in Gezi Park. The Drama Review, vol. 58(3), pp. 39-68. https://doi.org/10.1162/dram_a_00372

Rai, S. and Reinelt, J. (2014). The Grammar of Politics and Performance. London, New York: Routledge. https://doi.org/10.4324/9781315879871

Reddington, H. (2007). The Lost Women of Rock Music: Female Musicians of the Punk Era. London, New York: Routledge. https://doi.org/10.4324/9781315555935

Rose, T. (1994). Black Noise: Rap Music and Black Culture in Contemporary America. Hanover, N.H.: Wesleyan University Press.

Ross, A. (2010). The Rest is Noise: Listening to the Twentieth Century. New York: Picador.

Ross, A. (2011). Listen To This. London: Fourth Estate.

Rühlig, T. (2016). "Do You Hear the People Sing" "Lift Your Umbrella"? Understanding Hong Kong's Pro-democratic Umbrella Movement through YouTube Music Videos. China Perspectives, no. 2016/4, pp. 59-68. https://doi.org/10.4000/ chinaperspectives. 7125

Said, E. W. (1992). Musical Elaborations. London: Vintage Books.

Scott-Heron, G. (2012). The Last Holiday: A Memoir. London/New York: Canongate.

Şener, Ö. (2013). The Gezi Protests, Polyphony and 'Carnivalesque Chaos'. In: B. Gökay and I. Xypolia, eds., Reflections on Taksim-Gezi Park Protests in Turkey. Staffordshire: Keele European Research Centre.

Shapiro, M. J. (2004). Methods and Nations: Cultural Governance and the Indigenous Subject, London, New York: Routledge. https://doi.org/10.4324/9780203503775

Small, C. (1998). Musicking; The Meanings of Performing and Listening. Connecticut: Wesleyan University Press.

Smith-Spark, L. (2016). Bob Dylan wins 2016 Nobel Prize for Literature. CNN International Edition, October 13 2016. Available at: https://edition.cnn.com/2016/ 10/13/world/nobel-prize-literature/index.html

Stratton, J., and Zuberi, N. (2016). Black Popular Music in Britain since 1945. London: Ashgate/Routledge. https://doi.org/10.4324/9781315569482

Zehfuss, M., and Edkins, J. (2019). Global Politics: A New Introduction. $3^{\text {rd }}$ edition. London, New York: Routledge. https://doi.org/10.4324/9781315099118

Zuberi, N. (2017). Listening while Muslim. Popular Music, vol. 36(1). Cambridge University Press 2016, pp. 33-42. https://doi.org/10.1017/S0261143016000659 